\title{
Brand Equity and Brand Loyalty in the Internet Banking Context: FIMIX-PLS Market Segmentation
}

\author{
Sandra Maria Correia Loureiro ${ }^{1}$, Francisco Javier Miranda ${ }^{2}$ \\ ${ }^{1}$ Department of Economy, Management, and Industrial Engineering, University of Aveiro, Campus of Santiago Aveiro, Santiago, \\ Portugal; ${ }^{2}$ Departament of Business Management and Sociology, Univeristy of Extremadura, Economics and Business Faculty, \\ Badajoz, Spain. \\ E-mail: Sandra.loureiro@ua.pt, sandramloureiro@netcabo.pt,fmiranda@unex.es
}

Received September 21 $1^{\text {st }}$,2011; revised November $2^{\text {nd }}, 2011$; accepted November $22^{\text {nd }}, 2011$.

\begin{abstract}
This research presents a model that integrates trust, online risks and benefits, brand awareness/associations, perceived quality and explains how they impact on brand equity and brand loyalty in the context of internet banking. The research model estimation uses the PLS approach and applies FIMIX-PLS to segment the sample. The research findings show that the main difference characterizing the two uncovered customer segments lies in the place of residence. Thus, the impact of online benefits on trust in the service provided is stronger for the first segment than for the second. For customers of the second segment, confidence in the bank's web site information leads to a better perception of service quality and this is very important to ensure loyalty to the brand.
\end{abstract}

Keywords: Perceived Quality, trust, Brand Equity, Brand Loyalty, Finite Mixture Modeling

\section{Introduction}

Nowadays, the online service has grown in interest and adoption due to its convenience, ease of use, among other features. According to Pikkarainen et al. [1], since the middle of the last decade of the 20th Century, a radical change has taken place in banking delivery channels towards using self-service channels such as online banking services. Internet banking provides consumers with a set of information-related benefits that favors its adoption, including easy access, responsive systems, opportunity for the user to control bank accounts at any time and place, and access to personalized information content to make investment and finance decisions. Internet banking is also an easy way for the consumer to compare and contrast services [2,3].

In this study we follow the definition proposed by Pikkarainen et al. [1] to define internet banking: "an internet portal, through which customers can use different kinds of banking services ranging from bill payment to making investments". Thus, the focus is on technologies that customers use without any interaction with, or assistance from, bank employees. According to Meuter et al. [4], these technologies can be summarized as self-service technolo- gies or SSTs.

Several studies have been devoted to understand the factors that encourage or discourage the adoption or acceptance of SST, perceived risk, and trust [1,5-8]. As far as I know, little research exits on antecedents and consequences of internet banking brand equity. Thus, the purpose of this study is to examine the impact of brand associations/awareness, perceived quality, and internet banking trust on internet banking brand equity and also the impact of internet banking brand equity and perceived quality on brand loyalty, using the PLS approach. The finite mixture partial least squares (FIMIX-PLS), proposed by Hahn et al. [9] is also applied to segment the sample. This approach combines a finite mixture procedure with an expectation-maximization (EM)-algorithm specifically coping with the ordinary least squares (OLS)based predictions of PLS and enables reliable identification of distinctive customer segments, with their characteristic estimates for relationships of latent variables in the structural model.

\section{Theoretical Background and Hypotheses}

The concept of brand equity has been a field of interest to both firms and researchers for several years. There are 
several definitions of brand equity. One of the most widely accepted is the Farquhar's approach [10], which defines brand equity as added value for the company, for the delivery, or for the consumer. Later, Aaker [11] defines it as the sum of assets that are associated with the brand name, such as awareness, loyalty, perceived quality, as well as other proprietary assets. For Kapferer [12], brand equity is a reflection of the consumer and a mental image of proposed values (brand identity). Keller [13] claims that the basis of brand equity lays on brand knowledge and its positive associations. De Chernatony [14] defines it as a process, both internal and external to the organization, of offering a value proposal represented by the brand. Although the idea that brand equity adds value to the product or service is apparent in all these definitions, two different research approaches can be perceived: a business (or financial) perspective and a consumer perspective [15]. The approach based on the consumer perspective is one which concerns us in particular. According to Myers [16], the consumer perspective can also be divided in two ways: one based on consumer perceptions and the other based on his/her attitudes and behaviour.

Aaker [11] and Keller [17] have provided conceptual schemes that link brand equity with various consumer response variables. In general, there are direct and indirect measures of brand equity. As for the direct approach, an attempt is made to assess the value added by the brand to the product $[10,13]$. Specifically, Aaker [11] identified four major consumer-related bases of brand equity: brand loyalty, awareness, perceived quality, and brand associations. Keller [17] proposed a knowledge-based framework for creating brand equity, based on two dimensions: brand awareness and brand image. On the other hand, the indirect approach focuses on identifying potential sources of brand equity [11,17]. However, Keller [17] argues that the direct and indirect approaches are complementary and should be used together.

Park and Srinivasan [18] consider brand equity as the difference between overall brand preference and multiattributed preference based on objectively measured attribute levels, whereas Agarwal and Rao [19] regard it as an overall quality and choice intention. Based on the above considerations Yoo and Donthu [20] developed a multidimensional consumer-based brand equity scale. They also suggested that a potential causal order may exist among the dimensions of brand equity. Thus, the hierarchy of the effects model suggests that brand awareness and associations precede perceived quality and that perceived quality precedes brand loyalty [20]. The effect of high quality on brand loyalty is well known since it is the basis for consumer satisfaction [21-26].

Yoo et al. [27] demonstrated that the level of brand equity is positively related to the extent to which brand quality, brand loyalty, brand associations and awareness are evident in the product (e.g., athletic shoes, camera film, or color television sets). High perceived quality would drive a consumer to choose the brand rather than other competing brands. Therefore, brand equity will increase according to the degree that brand quality is perceived by consumers. Brand loyalty makes consumers purchase a brand routinely and resist switching to another brand. Hence, depending on the extent that consumers are loyal to the brand, brand equity will increase. However, brand loyalty could also be regarded as a potential outcome of brand equity. Several researchers pointed out that high brand equity is associated with high brand preference and loyalty $[28,30,14]$. The Chang and Liu's [29] model empirically supported the argument that brands with higher levels of brand equity would generate higher levels of customer brand preference. In turn, higher customer brand preference was associated with greater willingness to continue using the service brand.

Brand awareness and associations are both positively related to brand equity. If the consumers recognize, quickly recall, and are aware of the brand, this can be a sign of quality and commitment. Thus, a buyer aware of a brand with favorable associations in her/his mind and able to recognize quality is more willing to consider this brand at the time of purchase, which leads to a favorable behavior towards the brand. On the basis of the review of the literature, the following hypotheses are proposed (see Figure 1):

H1: Brand awareness/association exercises a positive impact on perceived quality.

H2: Perceived quality exercises a positive impact on brand loyalty.

H3: Brand awareness/association has a positive effect on internet banking brand equity.

H4: Internet banking brand equity has a positive effect on brand loyalty.

H5: Perceived quality has a positive effect on internet banking brand equity.

Trust has been studied primarily in the context of relationship marketing [31-33]. Morgan and Hunt [33] conceptualize trust "as existing when one part has confidence in an exchange partner's reliability and integrity". Rousseau et al. [34] defined trust as a "psychological state comprising the intention to accept vulnerability based on positive expectations of the intentions or behaviors of another”. Later, Bart et al. [35] adopted this last definition to the context of online trust.

Yoon [36] identify six factors (security assurance, brand, search, fulfillment, presentation, and technology) that formally represent the essence of online trust and, over time, they reflect on personality attributes such as dependability, reliability, and honesty. Yoon [36] also proposes 


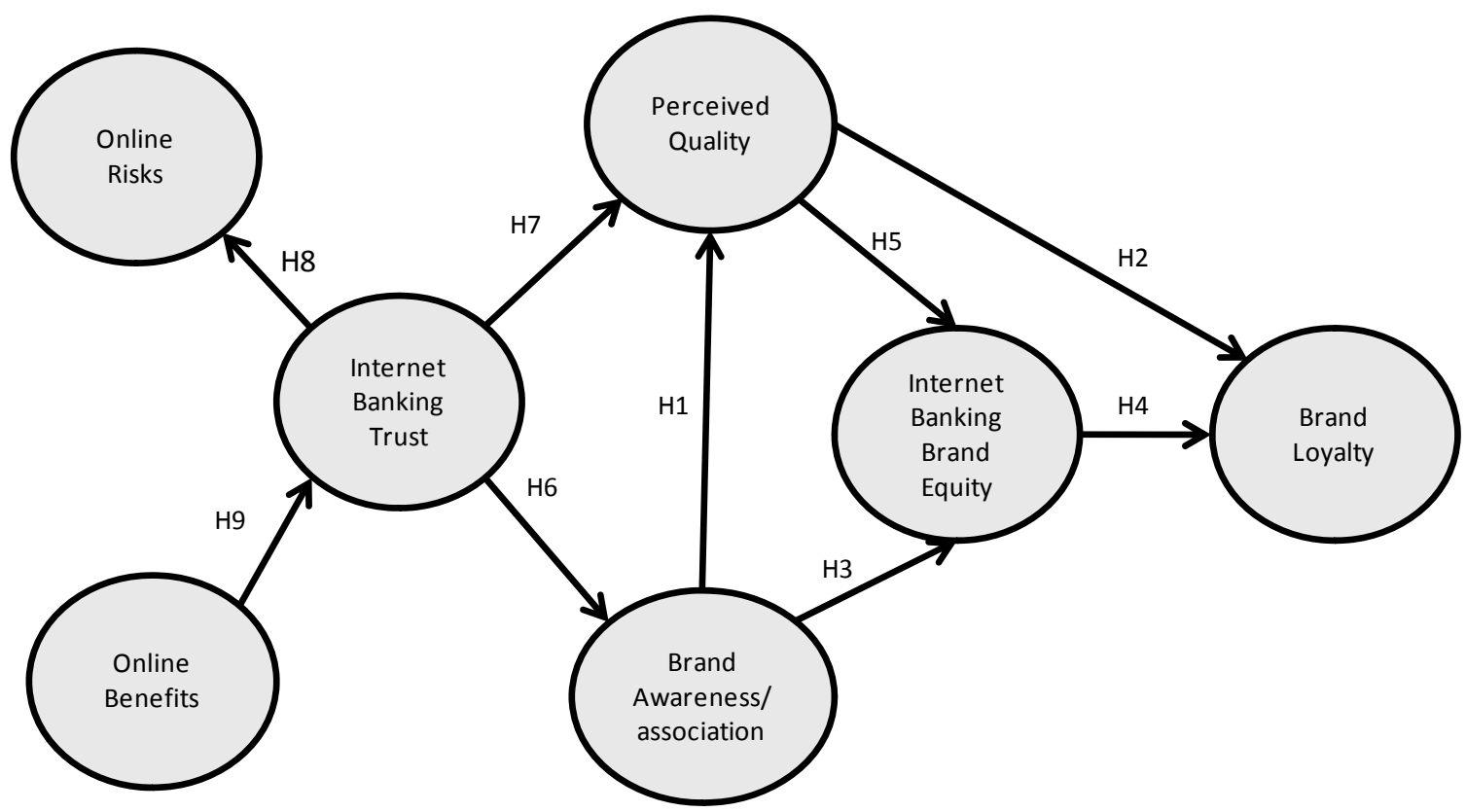

Figure 1. Proposed conceptual model.

that consumer awareness is a mediating variable in web site trust and satisfaction and suggests that online trust can exercise a positive effect on web site awareness.

In their seminal work Ambler [37] presents trust as an affective and not a cognitive, analytical construct which can be a proxy for brand equity. On the other hand, Kim et al. [38] empirically found that trust had a positive influence on brand awareness in the health care context. On the strength of the above considerations, the following hypotheses are proposed (see Figure 1):

H6: Internet banking trust positively influences brand awareness/association.

H7: Internet banking trust positively influences perceived quality.

Trust is largely associated with lower perceived risk and customers' perceptions of security and privacy. Trust acts as a mechanism designed to reduce consumers' perceived risk in internet shopping [39], reduces consumers' transaction-specific uncertainty and related risks associated with the possibility that a bank might behave opportunistically [40], and lowers the perceived risk of facing a negative outcome of a transaction by reducing information complexity [41]. However, the causal relational order between trust and perceived risk has not yet been clarified. This research follows the works of Aldás-Manzano et al. [7] and Yousafzai et al. [8] and states that high trust on internet banking reduces perceived risk. Moreover, perceived benefits of online banking (such as easiness to use and convenience) will help to build trust (see Figure 1).

H8: Internet banking trust exercises a negative effect on risk perceived by the e-banking consumer.

H9: Perceived benefits have a positive effect on internet banking trust.

\section{Method}

\subsection{Sample and Data Collection}

Drawing from literature review, a research model was constructed for this study to explain the relationship among brand awareness/association, perceived quality, internet banking trust, internet banking brand equity, perceived quality, and brand loyalty. The questionnaire, including the items of the latent variables and a section with the socio-demographic variables was first devised in English and then translated into Portuguese. Back translation was used to guarantee that the questionnaire communicated similar information to all respondents $[42,43]$. A pilot sample of twenty-three internet banking users (personally interviewed) was used to ensure that the wording of the questionnaire were clear.

In order to collect online banking users' information, we first required authorization from a large international and private bank operating in Portugal to express our need for the purposes of information research. After that, the private bank helped to email invitation letters to its users with a message explaining the need to understand their (the users') experience in the initial adoption of online banking services. The invitation letter also linked up to a web site where users could fill out an online questionnaire. The data analysis relies on 496 completed online questionnaires, conducted during July of 2009. The overall response rate was $34 \%$. 
Table 1. The demographic profile of the interviewed inhabitants of the Portugal.

\begin{tabular}{cc}
\hline Gender & Age \\
\hline & $18-25: 7.1 \%$ \\
& $26-35: 40.0 \%$ \\
& $36-45: 31.5 \%$ \\
& $46-55: 12.9 \%$ \\
Male: $67.5 \%$ & $56-65: 5.6 \%$ \\
& $66-75: 2.4 \%$ \\
& $>75: 0.5 \%$ \\
\hline
\end{tabular}

As Table 1 shows, most of the respondents were males. The majority of respondents (71.5\%) were between 26 and 45 year old. We gathered questionnaires from almost all the regions of Portugal regions, though mostly from Lisbon and Oporto.

\subsection{Variable and Measurement}

Brand awareness/associations, perceived quality, brand loyalty, and internet banking brand equity were operationalized on the basis of Yoo \& Donthu [27], Zeithaml et al. [26] and Keller [13,17]. Internet banking trust was measured using four items adapted from Bart et al. [35]. Online benefits and online risks were adapted from Forsythe et al. (2006). Each statement of the questionnaire was recorded on a 5-point Likert scale (1 = strongly disagree, 5 = strongly agree).

\subsection{Data Analysis}

The Partial Least Squares (PLS) approach was employed to estimate structural paths coefficients, R2, Q2, and the Bootstrap technique. PLS is based on an iterative combination of principal components analysis and regression, and aims to explain the variance of the constructs in the model [45]. In terms of advantages, PLS simultaneously estimates all path coefficients and individual item loadings in the context of a specified model and, as a result, enables researchers to avoid biased and inconsistent parameter estimates. Moreover, it has proved to be an effective analytical tool to test interactions by reducing type II error [46]. Nevertheless, PLS models are based on prediction-oriented measures, not covariance fit like covariance structure models developed by Karl Jöreskog (or LISREL program developed by Jöreskog and Sörborn). Besides the variance explained (i.e.R2), as an indicator of how well PLS has met its objective [47]and StoneGeisser's Q2 measure, which can be used to evaluate the predictive power of the model, Tenenhaus et al. [48] propose the geometric mean of the average communality (outer mode) and the average R2 (inner model) that is limited between values of 0 and 1 as overall goodness of fit (GoF) measures PLS (Cross validated PLS GoF) (see Equation 1).

$$
\text { GoF }=\sqrt{\overline{\text { communality }} \cdot \overline{R^{2}}}
$$

Following the analysis of the structural model, the finite mixture partial least squares (FIMIX-PLS) was applied to segment the sample based on the estimated scores for latent variables [49]. Finally, through a t-test, a parametric analysis was employed to determine if the segments were statistically different. For each segment the model was estimated once more and the precision of the PLS estimates was also analyzed. The parametric test uses the path coefficients and the standard errors of the structural paths calculated by PLS with the samples of the two segments, using the following expression of t-value for multi-group comparison test (2) ( $\mathrm{m}=$ segment 1 sample size and $\mathrm{n}=$ segment 2 sample size).

$$
\begin{aligned}
& t=\frac{\left(\beta_{\text {Segment 1 }}-\beta_{\text {Segment 2 }}\right)}{\sqrt[S p x]{\left(\frac{1}{m}+\frac{1}{n}\right)}} \\
& S p=\sqrt{\left[\frac{(m-1)^{2}}{(m+n-2)} X S E_{\text {Segment 1 }}^{2}+\frac{(N-1)^{2}}{(m+n-2)} X S E_{\text {Segment 2 }}^{2}\right]}
\end{aligned}
$$

The PLS model is analyzed and interpreted in two stages. First, the adequacy of the measures is assessed by evaluating the reliability of the individual measures and the discriminant validity of the constructs [50]. Then, the structural model is appraised.

The adequacy of the measures is assessed by evaluating the reliability of the individual items and the discriminant validity of the constructs [50]. Item reliability is assessed by examining the loading of the measures on their corresponding construct. All the loadings of scales that measure reflective constructs approximate or exceed 0.707 (see Table 2). This indicates that more than 50 percent of the variance in the observed variable is explained by the construct [51].

Composite reliability was used to analyze the reliability of the constructs since this has been regarded as a more exacting measurement than Cronbach's alpha [52]. Table 2 indicates that all constructs are reliable since the composite reliability values exceed the threshold of 0.7 and even the strictest one of 0.8 [53].

The measures demonstrated convergent validity as the average variance of manifest variables extracted by constructs (AVE) was at least 0.5 , indicative that more variance was explained than unexplained in the variables associated with a given construct. The criterion used to assess discriminant validity was the square root of AVE, which 
Table 2. Measurement results.

\begin{tabular}{|c|c|c|c|c|}
\hline Construct & LV Index Values & Item Loading & Composite reliability & AVE $^{*}$ \\
\hline Brand Awareness/associations & 4.1 & & 0.87 & 0.69 \\
\hline BAW1: I can recognize $\mathrm{x}$ among other competing brands & & 0.851 & & \\
\hline BAW2: I am aware of $x$ & & 0.895 & & \\
\hline BAW3: I can quickly recall the symbol or logo of $x$ & & 0.736 & & \\
\hline BAW4: I have difficulty in imagining $x$ in my mind. (r) & & a & & \\
\hline Perceived Quality & 3.6 & & 0.88 & 0.78 \\
\hline Q1: The quality of web site services provided by $\mathrm{x}$ is extremely high & & 0.903 & & \\
\hline Q2: The visual design of web site $x$ has a quality extremely high & & 0.867 & & \\
\hline Brand Loyalty & 3.6 & & 1.00 & 1.00 \\
\hline L1: I consider myself to be loyal to $x$ & & 1.000 & & \\
\hline Internet Banking Trust & 3.8 & & 0.93 & 0.82 \\
\hline T1: I have more confidence in this web site than other sites I have visited & & a & & \\
\hline T2: My overall trust in this site is high & & 0.864 & & \\
\hline T3: My overall believability of the information on this site is high & & 0.940 & & \\
\hline T4: My overall confidence in the recommendations on this site is high & & 0.909 & & \\
\hline Internet Banking Brand Equity & 3.4 & & 0.93 & 0.81 \\
\hline $\begin{array}{l}\text { BE1: I sign products in web site } \mathrm{x} \text { instead of any other bank, } \\
\text { even if they are identical }\end{array}$ & & 0.876 & & \\
\hline $\begin{array}{l}\text { BE2: Even if another bank has the same characteristics as } \mathrm{x} \text {, } \\
\text { I prefer to sign products in web site } \mathrm{x}\end{array}$ & & 0.925 & & \\
\hline $\begin{array}{l}\text { BE3: If there is a bank with an online service as good as } x \text {, } \\
\text { I prefer the } x\end{array}$ & & 0.900 & & \\
\hline Online Benefits & 4.1 & & 0.90 & 0.70 \\
\hline B1: I can sign products at home & & 0.876 & & \\
\hline B2: I can sign products whenever I want & & 0.843 & & \\
\hline B3: I can sign products online without going to the agency & & 0.830 & & \\
\hline B4: I sign products easily & & 0.796 & & \\
\hline Online Risks & 2.4 & & 0.90 & 0.60 \\
\hline R1: I feel lack of confidence in the web site & & 0.769 & & \\
\hline R2: I may not get the product I want & & 0.769 & & \\
\hline R3: I may sign something by accident & & 0.722 & & \\
\hline R4: There may be some technical failure & & 0.782 & & \\
\hline R5: It's difficult to get information about the product & & 0.788 & & \\
\hline R6: It's too complicated sign products & & 0.780 & & \\
\hline
\end{tabular}

*AVE Average Variance Extracted. (r) indicates reversed scoring. a indicates item eliminated. $\mathrm{x}$ indicates a brand name. 
Table 3. Discriminant validity analysis.

\begin{tabular}{|c|c|c|c|c|c|c|c|}
\hline \multirow[b]{2}{*}{ Construct } & \multicolumn{7}{|c|}{ Correlations of constructs } \\
\hline & $\begin{array}{c}\text { Brand } \\
\text { Awareness/associations }\end{array}$ & $\begin{array}{c}\text { Online } \\
\text { Benefits }\end{array}$ & $\begin{array}{l}\text { Internet Banking } \\
\text { Brand Equity }\end{array}$ & $\begin{array}{l}\text { Brand } \\
\text { Loyalty }\end{array}$ & $\begin{array}{l}\text { Perceived } \\
\text { Quality }\end{array}$ & $\begin{array}{l}\text { Online } \\
\text { Risks }\end{array}$ & $\begin{array}{c}\text { Internet } \\
\text { Banking } \\
\text { Trust }\end{array}$ \\
\hline $\mathrm{AVE}^{1 / 2}$ & 0.83 & 0.84 & 0.90 & 1.00 & 0.88 & 0.78 & 0.90 \\
\hline Brand Awareness/associations & 1.00 & 0.37 & 0.59 & 0.50 & 0.67 & -0.19 & 0.51 \\
\hline Online Benefits & 0.37 & 1.00 & 0.37 & 0.20 & 0.51 & -0.37 & 0.56 \\
\hline Internet Banking Brand Equity & 0.59 & 0.37 & 1.00 & 0.71 & 0.71 & -0.24 & 0.52 \\
\hline Brand Loyalty & 0.50 & 0.20 & 0.71 & 1.00 & 0.63 & -0.14 & 0.46 \\
\hline Perceived Quality & 0.67 & 0.51 & 0.71 & 0.63 & 1.00 & -0.27 & 0.68 \\
\hline Online Risks & -0.19 & -0.37 & -0.24 & -0.14 & -0.27 & 1.00 & -0.46 \\
\hline Internet Banking Trust & 0.51 & 0.56 & 0.52 & 0.46 & 0.68 & -0.46 & 1.00 \\
\hline
\end{tabular}

should be greater than the correlation between the construct and other constructs in the model [51]. Table 3 shows that all variables have discriminant validity.

The Blindfolding technique was used to calculate the Q2 and a nonparametric approach, called Bootstrap, to estimate the precision of the PLS estimates. Thus, 500 samples sets were created in order to obtain 500 estimates for each parameter in the PLS model. Each sample was obtained by sampling with replacement of the original data set $[52,45]$. As all values of Q2 are positive, the relations in the model have predictive relevance.

In the next analytical step, the FIMIX-PLS module of Smart PLS 2.0 was applied to segment the sample based on the estimated scores for latent variables. FIMIX-PLS results were computed for two, three, and four classes. The results reveal that the choice of two segments is appropriate for customer segmentation purposes. All relevant evaluation criteria considerably decrease in the ensuing numbers of segments (see Table 4) and each additional segment has only a small size, which explains a marginal portion of heterogeneity in the overall set of data. Over two thirds of all our observations are well assigned to one of the two classes with a probability of more than 0.7 .

Next, observations are assigned to each segment according to the segment membership's maximum a posteriori probability. The first segment represents $79 \%$ of the sample and the second segment $21 \%$. Table 5 shows the global model and FIMIX-PLS results for two latent segments. Before evaluating goodness-of-fit measures and inner model relationships, all outcomes for segment-specific path model estimations were tested with regard to reliability and discriminant validity. The analysis showed that all measures satisfy the relevant criteria for model evaluation [45].

All path coefficients of the global model are signifycant at a level of 0.001 or 0.05 , apart from the relation- ship between brand awareness/associations and internet banking brand equity. So, the H3 hypothesis is not supported. As shown in Table 5, the relationship between brand awareness/associations and internet banking brand equity is also not significant for the first and second segments either. The strength of the relationship between perceived quality and brand loyalty is higher for the second segment than for the first one. However, the strength of the relationship between internet banking trust and online risks seems to be weaker for the second segment than for the first one. Moreover, the two segments display significant differences, except for the structural paths: brand awareness/association - > internet banking brand equity, brand awareness/association - > perceived quality, perceived quality - > internet banking brand equity, and perceived quality - > brand loyalty.

The final step involves the analysis of each segment, using socio-demographic variables. The analysis reveals that the place of residence is the principal difference that characterizes the two uncovered customer segments.

Customers from the first segment, the largest of the sample, live mainly in Oporto (the second largest city in Portugal) and other inner northern and southern Portuguese regions. These customers ascribe special importance to the perceived online benefits. The perceived benefits have a strong and positive implication on internet banking trust and reducing online risk. Trust significantly contributes to improving the favorable associations/awareness to the brand.

Table 4. Model selection.

\begin{tabular}{lccc}
\hline & $\mathbf{K = 2}$ & $\mathbf{K = 3}$ & $\mathbf{K = 4}$ \\
\hline AIC (Akaike's Information Criterion) & 2903.8 & 3074.5 & 3046.3 \\
BIC (Bayesian Information Criterion) & 3007.6 & 3257.13 & 3231.83 \\
CAIC (Consistent AIC) & 3007.7 & 257.4 & 232.0 \\
EN (Normed Entropy Statistic) & 0.7689 & 0.6189 & 0.5020 \\
\hline
\end{tabular}


Table 5. Global model and disaggregate results for two latent segments.

\begin{tabular}{|c|c|c|c|c|}
\hline \multirow{2}{*}{ Structural Paths } & \multirow{2}{*}{ Global } & \multicolumn{3}{|c|}{ FIMIX-PLS } \\
\hline & & $K=1$ & $K=2$ & t[mgp] \\
\hline Brand Awareness/associations $\rightarrow$ Internet Banking Brand Equity & $0.2071 \mathrm{NS}$ & 0.1619 NS & $0.1521 \mathrm{NS}$ & $0.1700 \mathrm{NS}$ \\
\hline Brand Awareness/associations $\rightarrow$ Perceived Quality & $0.4334^{* * *}$ & $0.3985^{* * *}$ & $0.4251^{* * *}$ & $-0.7550 \mathrm{NS}$ \\
\hline Online benefits $\rightarrow$ Internet Banking Trust & $0.5557 * * *$ & $0.5797 * * *$ & $0.4025^{* * *}$ & $5.0152 *$ \\
\hline Internet Banking Brand Equity $\rightarrow$ Brand Loyalty & $0.5223^{* * *}$ & $0.5556^{* * *}$ & $0.4010^{* * *}$ & $2.0475^{*}$ \\
\hline Perceived Quality $\rightarrow$ Internet Banking Brand Equity & $0.5718^{* * *}$ & $0.6307 * * *$ & $0.6365^{* * *}$ & -0.1339 NS \\
\hline Perceived Quality $\rightarrow$ Brand Loyalty & $0.2636^{*}$ & $0.2687^{*}$ & $0.3683^{* * *}$ & $-1.3288 \mathrm{NS}$ \\
\hline Internet Banking Trust $\rightarrow$ Brand Awareness/associations & $0.5080 * * *$ & $0.5673^{* * *}$ & $0.3748^{* * *}$ & $4.0954^{*}$ \\
\hline Internet Banking Trust $\rightarrow$ Perceived quality & $0.4616^{* * *}$ & $0.4617^{* * *}$ & $0.5277^{* * *}$ & $-1.9585^{*}$ \\
\hline Internet Banking Trust $\rightarrow$ Online Risks & $-0.4646 * * *$ & $-0.4820^{* * *}$ & $-0.2796 * *$ & $-3.2465 *$ \\
\hline Segment sizes & 1.0000 & 0.7945 & 0.2055 & \\
\hline $\mathrm{R}^{2}$ Awareness/associations & 0.2580 & 0.3218 & 0.1405 & \\
\hline $\mathrm{R}^{2}$ Internet Banking Brand Equity & 0.5281 & 0.5588 & 0.5488 & \\
\hline $\mathrm{R}^{2}$ Brand Loyalty & 0.5379 & 0.6011 & 0.5124 & \\
\hline $\mathrm{R}^{2}$ Perceived quality & 0.6042 & 0.5807 & 0.6274 & \\
\hline $\mathrm{R}^{2}$ Online Risks & 0.2159 & 0.2323 & 0.0782 & \\
\hline $\mathrm{R}^{2}$ Internet Banking Trust & 0.3089 & 0.3361 & 0.1620 & \\
\hline GoF & 0.5618 & 0.5782 & 0.5082 & \\
\hline
\end{tabular}

$\mathrm{p}<0.5,{ }^{* *} \mathrm{p}<0.01,{ }^{* * *} \mathrm{p}<0.001$, NS = not significant. T[mgp] = t-value for multi-group comparison test (see expression 2).

Customers from the second segment live mainly in Lisbon (the capital and the largest Portuguese city). For these customers the perceived quality is very important to be loyal to the brand.

\section{Conclusions, Limitations and Future Research}

This research tests the differential effects of internet banking trust, perceived quality, and brand awareness/associations on internet banking brand equity and brand loyalty. At the aggregate level, online benefits positively affect internet banking trust, whereas trust exercises a negative effect on risk perceived by the e-banking consumers. Internet banking trust has a positive effect on perceived quality and brand awareness/associations. The ability to recognize, to be aware of, and to quickly recall the symbol or logo of the brand significantly contributes to the improvement of the perceived quality, but not internet banking brand equity. However, perceived quality of internet banking services is a good predictor of internet banking brand equity and brand loyalty. Therefore, brand loyalty can be seen as an outcome of internet banking brand equity.

The findings prompt us to state that managers should be attentive to the quality of web sites services and their visual design, conscious of the need to improve on them. The visual design of the web site should be in accordance to the positive and favorable associations that most clo- sely correlate with the identity and positioning desired for the brand.

The positive albeit not significant relationship between brand awareness/associations and internet banking brand equity (H3 hypothesis) is consistent with the empirical evidence of Faircloth, Capella and Alford's study [54]. They found that brand image directly influences brand equity, but positive brand attitude, one of the several types of brand association [17], only has an indirect effect on enhanced brand equity.

This study also provides an application of the finite mixture partial least squares (FIMIX-PLS) to capture heterogeneity in PLS path modeling of brand awareness/ associations, perceived quality, internet banking trust, internet banking brand equity, and brand loyalty. This approach enabled us to identify two segments of customers that result in heterogeneity within the inner model. This led us to observe that the impact of online benefits on trust in the service provided is stronger in the first segment than in the second. Confidence in the recommendations and information on the bank web site contributes to reduce the perceptions of online risks. It also helps to encode the brand name in the customer's mind and enables him/her to recall and recognize such a name or, at least, to improve the favorable associations/awareness of the brand, especially where the first segment customers are concerned. For customers living mainly in Lisbon, confidence in the bank's web site information leads to a bet- 
ter perception of service quality, which is very important in ensuring loyalty to the brand.

The differences encountered may be related to lifestyle, the frequency of recourse to internet banking, since customers from the second segment live mainly in Lisbon (the capital and the largest Portuguese city). These customers (living in the big Lisbon) tend to have a lifestyle that lead them to spend much time on the route between home and work (and reverse), so they tend to adopt more often and critically the online services. However, further research is required to understand and to explain the findings. Future research should also examine other negative constructs, such as dissatisfaction factors. The author considers it is also important to introduce variables like communication or commitment, and credibility, and to improve the items used in the variables

Finally, the FIMIX-PLS methods could prove to be very interesting in the case of managerial practices as it can grasp differences even in a small country such as Portugal, where one does not anticipate a significant behavior difference.

\section{REFERENCES}

[1] P. Tero, K. Pikkarainen, H. Karjaluoto and S. Pahnila, "Consumer Acceptance of Online Banking: An Extension of the Technology Acceptance Model," Internet Research, Vol. 14, No. 3, 2004, pp. 224-235. doi:10.1108/10662240410542652

[2] M. J. Bitner, A. L. Ostrom and M. L. Meuter, "Implementing Successful Self-Service Technologies,” The Academy of Management Executive, Vol. 16, No. 4, 2002, pp. 96-108. doi:10.5465/AME.2002.8951333

[3] D. S. Johnson, “Achieving Customer Value from Electronic Channels through Identity Commitment, Calculative Commitment and Trust in Technology," Journal of Interactive Marketing, Vol. 21, No. 4, 2007, pp. 2-22. doi:10.1002/dir.20091

[4] M. L. Meuter, A. L. Ostrom, R. L. Roundtree and M. J. Bitner, "Self-service Technologies: Understanding Customer Satisfaction with Technology-Based Service Encounters," Journal of Marketing, Vol. 64, No. 3, 2000, pp. 50-64. doi:10.1509/jmkg.64.3.50.18024

[5] G.-K. Sonja and R. Faullant, "Consumer Acceptance of Internet Banking: The Influence of Internet Trust," International Journal of Bank Marketing, Vol. 26, No. 7, 2008, pp. 483-504. doi:10.1108/02652320810913855

[6] M.-C. Lee, "Factors Influencing the Adoption of Internet Banking: An Integration of TAM and TPB with Perceived Risk and Perceived Benefit," Electronic Commerce Research and Applications, Vol. 8, 2008, pp. 130141. doi:10.1016/j.elerap.2008.11.006

[7] J. Aldás-Manzano, C. Lassala-Navarré, C. Ruiz-Mafé and S. Sanz-Blas, "Key Drivers of Internet Banking Services Use,” Online Information Review, Vol. 33, No. 4, 2009, pp. 672-695. doi:10.1108/14684520910985675
[8] Yousafzai, Shumaila, J. Pallister and G. Foxall, "MultiDimensional Role of Trust in Internet Banking Adoption,” The Service Industries Journal, Vol. 29, No. 5, 2009, pp. 591-605. doi:10.1080/02642060902719958

[9] Hahn, Carsten, M. D. Johnson, A. Herrmann and F. Huber, "Capturing Customer Heterogeneity Using a Finite Mixture PLS Approach,” Schmalenbach Business Review, Vol. 54, No. 3, 2002, pp. 243-269.

[10] P. H. Farquhar, “Managing Brand Equity,” Marketing Research, Vol. 1, 1989, pp. 24-33.

[11] A. David, "Managing Brand Equity: Capitalizing on the Value of a Brand Name," The Free Press, New York, 1991.

[12] J.-N. Kapferer, "Strategic Brand Management: Creating and Sustaining Brand Equity Long Term,” Kogan Page, London, 1998.

[13] K. Kevin Lane, "Brand Synthesis: The Multidimensionality of Brand Knowledge," Journal of Consumer Research, Vol. 29, No. 4, 2003, pp. 595-600. doi:10.1086/346254

[14] C. Leslie de, "From Brand Vision to Brand Evaluation: Strategically Building and Sustaining Brands," Butterworth-Heinemann, Oxford, 2003.

[15] Pappu, Ravi, P. G. Quester and R. W. Cooksey, "Consumer-Based Brand Equity: Improving the Measurement-Empirical Evidence," Journal of Product \& Brand Management, Vol. 14, No. 3, 2005, pp. 143-154. doi:10.1108/10610420510601012

[16] C. A. Myers, "Managing Brand Equity: A Look at the Impact of Attributes," Journal of Product and Brand Management, Vol. 12, No. 1, 2003, pp. 39-51. doi:10.1108/10610420310463126

[17] K. Kevin Lane, "Conceptualizing, Measuring, and Managing Customer-Based Brand Equity," Journal of Marketing, Vol. 57, 1993, pp. 1-22. doi:10.2307/1252054

[18] P. Chan Su and V. Srinivasan, "A Survey-Based Method of Measuring and Understanding Brand Equity and its Extendibility,” Journal of Marketing Research, Vol. 31, No. 2, 1994, pp. 271-288. doi:10.2307/3152199

[19] M. K. Agarwal and V. R. Rao, "An Empirical Comparison of Consumer-Based Measures of Brand Equity," Marketing Letters, Vol. 7, No. 3, 1996, pp. 237-247. doi:10.1007/BF00435740

[20] Y. Boonghee and N. Donthu, "Developing and Validating a Multidimensioanl Consumer-Based Brand Equity Scale,” Journal of Business Research, Vol. 52, 2001, pp. 1-14. doi:10.1016/S0148-2963(99)00098-3

[21] R. L. Oliver, "Measurement and Evaluation of Satisfaction Processes in Retail Settings," Journal of Retailing, Vol. 57, 1981, pp. 25-48.

[22] M. J. Bitner, "Evaluating Service Encounters: The Effects of Physical Surroundings and Employee Responses," Journal of Marketing, Vol. 54, No. 4, 1990, pp. 69-82. doi:10.2307/1251871

[23] C. J. Joseph, Jr., M. K. Brady, G. Tomas and M. Hult, "Assessing the Effects of Quality, Value, and Customer 
Satisfaction on Consumer Behavioural Intentions in Service Environments," Journal of Retailing, Vol. 76, No. 2, 2000, pp. 193-218. doi:10.1016/S0022-4359(00)00028-2

[24] F. Claes, “A National Customer Satisfaction Barometer: The Swedish Experience,” Journal of Marketing, Vol. 56, No. 1, 1992, pp. 6-21. doi:10.2307/1252129

[25] A. Parasuraman, L. L. Berry and V. A. Zeithaml, "Refinement and Reassessment of the SERVQUAL Scale," Journal of Retailing, Vol. 67, No. 4, 1991, pp. 420-450.

[26] V. A. Zeithaml, L. Berry and A. Parasuraman, "The Behavioural Consequences of Service Quality,” Journal of Marketing, Vol. 60, No. 2, 1996, pp. 31-46. doi:10.2307/1251929

[27] Y. Boonghee, N. Donthu and S. Lee, "An Examination of Selected Marketing Mix Elements and Brand Equity," Journal of Academy of Marketing Science, Vol. 28, No. 2, 2000, pp. 195-211. doi:10.1177/0092070300282002

[28] C. J. Cobb-Walgren, C. A. Ruble and N. Donthu, "Brand Equity, Brand Preference, and Purchase Intent,” Journal of Advertising, Vol. 24, No. 3, 1995, pp. 25-40.

[29] H. H. Chang and Y. M. Liu, "The Impact of Brand Equity on Brand Preference and Purchase Intentions in the Service Industries,” The Service Industries Journal, 29, No. 12, 2009, pp. 1687-1706. doi:10.1080/02642060902793557

[30] J. F. Devlin, A. L. Gwynne and C. T. Ennew, “Antecedents of Service Expectations," The Services Industries Journal, Vol. 22, No. 4, 2002, pp. 117-131. doi:10.1080/714005102

[31] P. M. Doney and J. P. Cannon, "An Examination of the Nature of Trust in Buyer-Seller Relationships,” Journal of Marketing, Vol. 61, 1997, pp. 35-51. doi:10.2307/1251829

[32] G. Shankar and R. L. Hess, "Dimensions and Levels of Trust: Implications for Commitment to a Relationship," Marketing Letters, Vol. 8, No. 4, 1997, pp. 439-448.

[33] R. M. Morgan and S. D. Hunt, "The Commitment-Trust Theory of Relationship Marketing,” Journal of Marketing, Vol. 58, 1997, pp. 20-38. doi:10.2307/1252308

[34] D. M. Rousseau, S. B. Bitkin, R. S. Burt and C. Camerer, "Not So Different After All: A Cross-Discipline View of Trust," Academy of Management Review, Vol. 23, No. 3, 1998, pp. 393-404. doi:10.5465/AMR.1998.926617

[35] B. Yakov, V. Shankar, F. Sultan and G. L. Urban, “Are the Drivers and the Role of Online Trust the Same for All Web Sites and Consumers? A Large-Scale Exploratory Empirical Study,” Journal of Marketing, Vol. 69, 2005, pp. 133-152. doi:10.1509/jmkg.2005.69.4.133

[36] S.-J. Yoon, "The Antecedents and Consequences of Trust in Online Purchase Decisions," Journal of Interactive Marketing, Vol. 16, 2002, pp. 47-63. doi:10.1002/dir.10008

[37] A. Tim, "How Much of Brand Equity is Explained by Trust?” Management Decision, Vol. 35, No. 4, 1997, pp. 283-292. doi:10.1108/00251749710169666

[38] K. K. Hoon, S. K. Kang, Y. K. Dong, H. K. Jong and S.
H. Kang, "Brand Equity in Hospital Marketing," Journal of Business Research, Vol. 6, 2008, pp. 75-82.

[39] S. L. Jarvenpaa and P. A. Todd, "Consumer Reactions to Electronic Shopping on the World Wide Web," International Journal of Electronic Commerce, Vol. 2, 1997, pp. 59-88.

[40] Y. Shumaila, J. Pallister and G. Foxall, "A Proposed Model of E-Trust for Electronic Banking,” Technovation, Vol. 23, No. 11, 2003, pp. 847-860. doi:10.1016/S0166-4972(03)00130-5

[41] R. C Mayer, J. H. Davis and F. D. Schoorman, "An Integrative Model of Organizational Trust,” Academy of Management Review, Vol. 20, No. 3, 1995, pp. 709-734. doi:10.2307/258792

[42] R. W. Brislin, "Back-Translation for Cross-Cultural Research,” Journal of Cross-Cultural Psychology, Vol. 1, No. 13, 1970, pp. 185-216. doi:10.1177/135910457000100301

[43] S. Uma, "Methodological and Theoretical Issues and Advancements in Cross-Cultural Research," Journal of International Business Studies, Vol. 14, No. 2, 1983, pp. 61-73. doi:10.1057/palgrave.jibs.8490519

[44] F. Sandra, C. Liu, D. Shannon and L. C. Gardner, "Development of a Scale to Measure the Perceived Benefits and Risks of Online Shopping," Journal of Interactive Marketing, Vol. 20, No. 2, 2006, pp. 55-75. doi:10.1002/dir.20061

[45] W. W. Chin, "The Partial Least Squares Approach to Structural Equation Modeling," Modern Methods for Business Research, In: G. A. Marcoulides, Ed., Lawrence Erlbaum Associates Publisher, New Jersey, 1998, pp. 295-336.

[46] W. W. Chin, B. L. Marcolin and P. R. Newsted, “A Partial Least Squares Latent Variable Modelling Approach for Measuring Interaction Effects: Results from a Monte Carlo Simulation Study and an Electronic Mail Emotion/ Adoption Study," Information Systems Research, Vol. 14, No. 2, 2003, pp. 189-217. doi:10.1287/isre.14.2.189.16018

[47] B. Donald, R. Thompson and C. Higgins, "The Partial Least Squares (PLS) Approach to Causal Modeling, Personal Computer Adoption and Use as an Illustration," Technology Studies, Vol. 2, 1995, pp. 285-309.

[48] T. Michel, V. E. Vinzi, Y.-M. Chatelin and C. Lauro, "PLS Path Modeling," Computational Statistics \& Data Analysis, Vol. 48, 2005, pp. 159-205. doi:10.1287/isre.14.2.189.16018

[49] C. M. Ringle, S. Wende and W. Alexander, Smart PLS 2.0 (beta), www.smartpls.de, Hamburg, 2005,

[50] J. Hulland, "Use of Partial Least Squares (PLS) in Strategic Management Research: A Review of Four Recent Studies,” Strategic Management Journal, Vol. 20, No. 2, 1999, pp. 195- 204. doi:10.1002/(SICI)1097-0266(199902)20:2<195::AID-S MJ13>3.3.CO;2-Z

[51] E. G. Carmines and R. A. Zeller, "Reliability and Validity Assessment,” Sage Publications, Inc., London, 1979, 
[52] F. Claes and D. F. Larcker, "Evaluating Structural Models with Unobservables Variables and Measurement Error," Journal of Marketing Research, Vol. 28, 1981, pp. 39-50.

[53] J. C. Nunnally, "Psychometric Theory," 2nd Edition, McGraw-Hill, New York, 1978.
[54] J. B. Faircloth, L. M. Capella and B. L. Alford, "The Effect of Brand Attitude and Brand Image on Brand Equity,” Journal of Marketing Theory and Practice, 2001, pp. 61-75. 